of the water needed by the population of Egypt, nevertheless many questions connected with the increase of population in towns and with intensive cultivation have lately directed attention to the position and the movements of the water-table in the alluvial plain of the Lower Nile. After some preliminary work in previous years, a more systematic investigation was started in Upper Egypt from Aswan to Cairo, in $1907-8$, to obtain definite information. This has now been published in the form of a departmental paper by Mr. H. T. Ferrar, of the Geological Survey of Egypt. ${ }^{1}$ Observations were made at 239 wells which were visited, and the water-level recorded an average of eight times during the twelve months from one flood of the river to the next; since no rainfall occurs to complicate the conditions, these data were sufficient to define with adequate accuracy the range and movement of the water-table in that year. The rock trough in which the Nile flows is largely filled by pleistocene sands and gravels, over which the alluvial deposits have been laid down, and into these the wells from which water-wheels lift water are usually dug down through the alluvium and into the underlying sands; from these wells most of the observations were taken. At many points the Nile itself has cut into these sandy diluvial deposits, or flows against them at the margin of the valley, so that the river water is in communication with both deposits. A series of diagrams show the variation of the water-level in each well throughout the year, and also the position of the water-table for each month at fifteen different points of the river. Slight differences due to variations in porosity, \&c., are to be seen, but the whole gives a very clear picture of the movement of subsoil water. The lines for September and October show its rapid rise, after which the fall commences, being greatest between December and January and afterwards decreasing. In these later months there is often a slope towards the river, and an appreciable amount of stored water is then returned from the flood plain to the river. It would have been preferable if the observed values had been indicated on the diagrams and the depths of the wells drawn, as the curves do not show to what extent they are ccintrolled by data without reference to the printed tables.

In subsequent chapters an attempt is made to compute the quantity of water which the alluvial plain can hold, 60 per cent. by volume being taken as the water absorbed by the soil, but measured discharges of the river and canals are not utilised, and the values obtained cannot be regarded as more than rough approximations. Data for determining the direction of movement are scanty; near the river, results vary greatly within short distances, and in villages any use of colouring matter in such investigations would arouse much hostility. A large amount of valuable data has been collected, which greatly increases our knowledge of the water in the Nile valley, and must be of the greatest value for agriculture and for public health. The wells of the flood-plain are grouped into those of the river margin which are immediately affected by its changes of level, those of the plain which have an annual rise and fall about a month and a half after that of the river, and those close to the desert margin where the range is comnaratively small. Further investiogation on the same lines has been carried on since in the delta, which will be published in due course, forming a study of much value which, it is to be hoped, will be continued in the future.

THE ROYAL OBSERVATORY, GREENWICH.

$M R$. DYSON'S first report-as Astronomer Royal-was held at Greenwich on June 2 and covers the of Visitors May ro. Below we give a brief summary.

The transit circle was employed for the usual observations and for the observation of stars of magnitude $9 \cdot 0$ and brighter between $+24^{\circ}$ and $+32^{\circ}$ north declination The latter research, commenced in 1906 with the intention of securing five observations of each star, includes some I 2,000 stars, and about 48 per cent. of the observations were completed at the date of report.

From the transit-circle and altazimuth observations of the moon's limb and Mösting A, made during I909, the

1 "The Movements of the Subsoil Water in Upper Egypt." By H. T.
Ferrar. (Cairo: Survey Dept. Paper No. I9, Igrr.)

NO. 217 I, VOL. 86$]$ mean error of the moon's tabular place was found to be $-0.423 \mathrm{~s}$. in R.A. and $-0.53^{\prime \prime}$ in N.P.D.; from ninetyeight observations with the transit-circle, the mean error in R.A., for Igro, was found to be $-0.543 \mathrm{~s}$.

A new mercury trough has been added to the altazimuth. It is carried on iron rails quite isolated from the floor, and the steadiness of the star images has become greatly improved.

Values for the moon's parallax have been obtained from the Cape-Greenwich observations of Mösting A, made during 1905-10, and the probable error of the result, so far as it is independent of the earth's ellipticity, is $\pm 0.06^{\prime \prime}$. For values of $\mathrm{I} / e$ ranging from 293 to 300 , the correction to Hansen's value of the parallax ranges from +0.53 " to $+0.12^{\prime \prime}$; the combined results give $+0.44^{\prime \prime}$ as the correction and 294.5 as the value of $1 / e$.

Bimonthly investigations of the R-D discordance revealed a nearly constant discordance, amounting to $\mathrm{I} \cdot \mathrm{I} 4^{\prime \prime}$, in the yearly mean, which changes sign when the instrument is reversed, and although the object-glass has been remounted, the cause of this has not yet been discovered.

The mean error in R.A. of the moon's tabular place for 1910 is $-0.59 \mathrm{~s}$. from meridian observations of the $\operatorname{limb}$ and $-0.55 \mathrm{~s}$. from those of Mösting $\mathrm{A}$.

The reflex zenith tube observations for $1906-9$, discussed by $\mathrm{Mr}$. Eddington, give results in fair accordance, on the whole, with those published by Dr. Albrecht for the International Latitude Service.

About 600 double-star observations were made with the 28 -inch refractor, including observations of i to pairs under $0.5^{\prime \prime}$ separation and ${ }_{53}$ pairs between $0.5^{\prime \prime}$ and 1.0 ".

In the 30-inch Thompson equatorial the mirror, last silvered in February, 1910, is still in good condition owing to the cover having been made air-tight by a band of pure rubber. This instrument was employed in photographing Saturn and its ninth satellite, comets Igogc and $1910 b$ and $e$, and some of Herschel's nebulæ, the latter for identification and position determination.

The 26-inch refractor was chiefly employed in the photographic determination of the parallaxes of stars in the Greenwich astrographic zone, Kapteyn's method of exposures on the same plate at intervals of six months being followed.

As the southern declination of Jupiter made observations at Greenwich impossible, the director of the Helwan Observatory undertook to continue the observations of $\mathrm{J}$ viii, and eight photographs, taken on eight nights, have already been received at Greenwich for measurement. Approximate measures of the first two photographs of the satellite indicate that the Cowell-Crommelin ephemeris is only $20^{\prime \prime}$ in error.

Since November, the Greenwich astrographic telescope has been employed in the photographic determination of the magnitudes of stars given in the two published volumes of the Greenwich zones, Pickering's plan of polar sequences being employed.

An interesting investigation now being carried out at the observatory is the enumeration of the stars of different magnitudes on the photographs of the whole sky taken by Mr. Franklin-Adams, who is bearing the cost. Twentysix plates, covering the sky between the North Pole and $+53^{\circ}$, have been dealt with, and 42,284 stars counted. The greatest number counted on any one plate (in twentyfive $20^{\prime}$ squares) was $5^{1} 3^{8}$, the least $30 \mathrm{r}$.

The Dallmeyer photoheliograph is now housed in the dome of the old altazimuth, where one quarter of the original dome was cut away and a corresponding sector fixed permanently in the north, so that the large domeaperture thus secured is easily closed by bringing it under the fixed sector. For I910 the solar photograph record is complete, the ninety gaps in the combined Greenwich and Cape series having been filled by photographs received from the Dehra Dûn and Kodaikánal observatories in India. Since the beginning of May, one of the photoheliograph observers has attended from 7 to 9 a.m., thus adding two hours to the period of observation, and also securing better results.

The mean daily spotted area of the sun's disc in rgro was less than half that of 1900 , and during the five months ended March 31, IOII, the disc was free from spots on sixty-seven days. During the rapidly approaching minimum the direction of the sun's axis is to be determined 
from the thirty-seven years' observations now available.

The principal results for the magnetic elements in 1910 were :-

Mean declination $\quad \ldots \quad \ldots \quad \ldots \quad \ldots 5^{\circ} 4 \mathrm{I} \cdot 2^{\prime \prime}$ West.

Mean horizontal force $\quad \ldots . \quad \ldots .60 .18532$ (C.G.S. units.) Mean dip (with 3 -inch needles) $\ldots .666^{\circ} 52^{\prime} 37^{\prime \prime}$.

There were no days of "great," and only six of "lesser," magnetic disturbances.

The mean temperature for $1910,49.7^{\circ}$, was $0 \cdot 1^{\circ}$ above the $184 \mathrm{I}-95$ average, but the sunshine recorder showed a deficiency; July provided only about half the average number of hours of bright sunshine, and May was the only month when the amount was appreciably above the average. The rainfall, 25.93 inches, was $\mathrm{I} .8 \mathrm{I}$ inches in excess of the 1841-95 average, and the number of "rainy days "was 175 .

In the time department, the performance of chronometers is reported as satisfactory, and that of chronometer watches as exceptionally good. The increase of electrical devices on board ships having made the question of the magnetic disturbance of chronometers an urgent one, special experiments are being carried out with strong magnetic fields at the observatory.

\section{THE HARD AND SOFT STATE OF METALS.}

DR. G. T. BEILBY, F.R.S., delivered the second Friday, May 12, taking for his subject "The Hard and Soft States in Metals."

In the course of his lecture Dr. Beilby said that the hardening effect of cold working on ductile metals, and the softening effect of reheating, must have been known to the earliest workers in metals. To the general mind, the phenomena were sufficiently explained as being due to the "compacting" effect of hammering and the "opening up " effect of heat. The advent of scientific methods of inquiry led to the exposure of this fallacy, and to the discovery of new points of difference in a metal in the two states. The discovery that the polishing of all substances, even of those so hard or brittle as antimony or calespar, involves the transient liquefaction of $a$ thin layer on the surface, led to the study of this subject from an entirely new point of view. In a pure ductile metal which has been slowly cooled from the molten state, the structure of the solid is completely crystalline, and the metal is in its softest condition. Any permanent deformation of the mass, whether by hammering, by rolling, or by wire drawing, hardens and stiffens it. The microscopic examination of the hardened metal shows that its original crystalline structure has been broken up and replaced by a new type of structure. If the hardened metal is raised to a sufficient temperature, the softness is completely restored and the crystalline structure is also restored. In the ductile metals the greatest degree of softness is always associated with well-developed crystallisation.

The composite character of the hardened structure, which in some cases resembles a bed of broken and distorted strata concreted or cemented together by a matrix, can only be explained by the presence of two constituents, namely, the broken-down remains of crystals and an amorphous or glass-like form of the metal by which the mass is so firmly cemented together that it has become vastly more rigid and mechanically stable than the crystalline structure. This amorphous or vitreous form of the metal stands in the same relation to the crystalline form as glass does to the crystalline silicates of which it is composed, or as the clear, vitreous "barley sugar" does to the ordinary crystals of the breakfast table.

The pure ductile metals cannot be obtained in the vitreous state by cooling, because their molecules retain sufficient mobility to enable them to marshal themselves in crystalline formation for a range of about $800^{\circ}$. below the solidifying point. All the facts show, however, that when liquefaction is produced by mechanically induced flow the solidification is so rapid that the solid which results is in the vitreous condition.

NO. 2 I 7 I, VOL. 86$]$
Microscopic analysis of the surface skin produced by polishing a plate of calcite shows that the disturbance due to polishing has penetrated to a depth of one thousandth of a millimetre, and that the subsequent healing over of the disturbance has been so perfect that it can only be explained by the assumption that the transient liquefaction of a layer some thousands of molecules in thickness has occurred. It is evident that the conditions necessary to bring about liquefaction and solidification at the outer surface must equally exist within the substance at al surfaces of slip or shear, and the microstructure of the hardened metal confirms this view.

The direct bearing of these researches on the obscure subject of molecular structure in solids was pointed out, and a "pulsation cell" hypothesis of the three states of matter was outlined.

Prof. Quincke's "foam-cell" theory of solidification was referred to, and was applied to the explanation of certain observations made by Prof. Carpenter some years ago. In view of the possible bearing of this theory on questions of foundry practice, it was suggested that the Institute of Metals might offer a prize for the best research on the subject.

HYDRO-ELECTRIC PLANTS IN NORWAY AND THEIR APPLICATION TO ELECTRO. CHEMICAL INDUSTRY. ${ }^{\mathrm{B}}$

'THE physical configuration of Norway is remarkably favourable for the utilisation of the large number of waterfalls to be found on the seaboard of the mountain chains which almost cover the country, and through the valleys of which the enormous quantity of water precipitated from the western and south-eastern sea breezes finds its way as rivers flowing down to the sea. In the winter the rainfall takes the form of snow, so that the volume of water brought down by the rivers is at its greatest from May to July, when the snows melt on the mountains. To make use of the water-power, storage is therefore necessary, and for this the nature of the country is peculiarly adapted, being covered with lakes that have very contracted outlets, and which can be easily converted by damming into storage reservoirs. Thus in the watershed of Skien the natural water-power of 50,000 horsepower has been increased to an available horse-power of 375,000 , while the Mösvand reservoir has increased the water-power of the Rjukan factories from 30,000 to 250,000 horse-power, with a capital outlay of only some $85,000 l$.

The total water-power in Norway has been estimated at from five to seven million horse-power, but as much of the country has not been hydrographically surveyed, this is probably too low an estimate. The power stations can supply power at from 22s. to $44 s$. per e.h.p.-year, and in some cases even for less; and as the quantities available are as high as from 50,000 to 100,000 horse-power for a single fall, the conditions are ideal for the development of electrochemical and electrometallurgical industries. Many such industries have already reached an advanced stage of development. Thus nearly 180,000 horse-power will be utilised this year in the manufacture of nitrates of lime, soda, and ammonia from the air by the Birkeland-Eyde process and the Badische Analin und Sodafabrik Company's process; about 60,000 horse-power are employed in the manufacture of calcium carbide, and other electrochemical and electrometallurgical industries absorb at present some 20,000 horse-power. Now that a suitable electric furnace-the Grönwall-has been designed for the smelting of iron ore, a furnace that has yielded excellent results on a practical scale, electric iron and steel smelting is likely to develop largely in the near future, for Norway possesses extensive deposits of iron ore. Three plants, aggregating 16,000 horse-power, with provision for increasing to nearly 60,000 , are now being erected at Hardanger, Arendal, and Tinfoss. Other ores, notably copper, nickel, zinc, will also possibly be electrically smelted at no distant date.

The second portion of the paper describes in some detail the various hydro-electric schemes now being developed in

1 Strmmary of a paper read before the Fara say Society on May 2, by Mr. A. Scott-Hansen, of Christiania. 